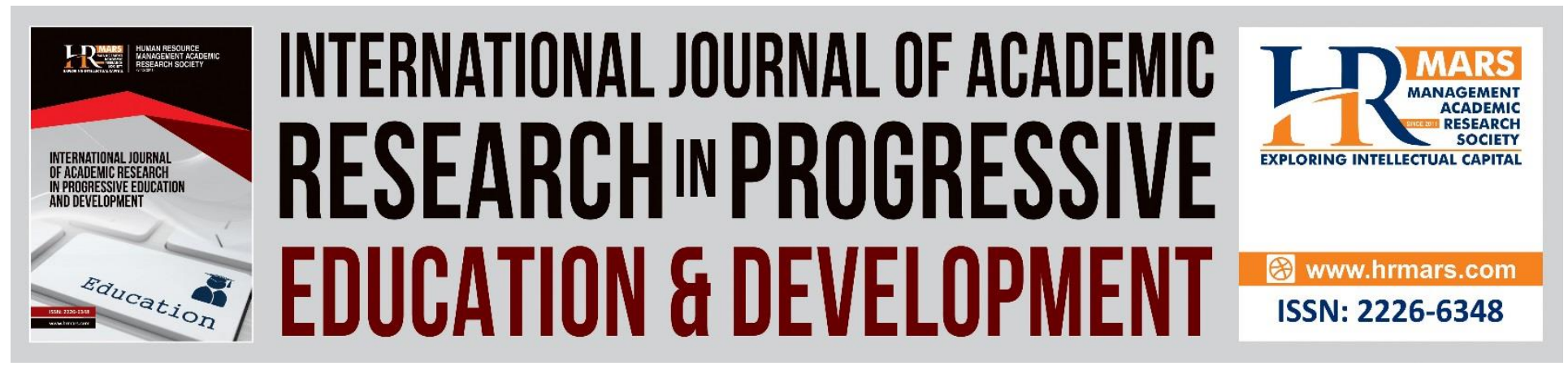

\title{
The Relation of Human Capital and Competitiveness Factor towards Graduate Competencies
}

\section{Marfunizah Binti Ma'dan, Muhamad Takiyuddin Bin Ismail, Sity Daud}

To Link this Article: http://dx.doi.org/10.6007/IJARPED/v8-i4/6761

DOI:10.6007/IJARPED/v8-i4/6761

Received: 11 November 2019, Revised: 30 November 2019, Accepted: 17 December 2019

Published Online: 30 December 2019

In-Text Citation: (Ma'dan et al., 2019)

To Cite this Article: Ma'dan, M. B., Ismail, M. T. Bin, \& Daud, S. (2019). The Relation of Human Capital and Competitiveness Factor towards Graduate Competencies. International Journal of Academic Research in Progressive Education and Development, 8(4), 824-835.

Copyright: (C) 2019 The Author(s)

Published by Human Resource Management Academic Research Society (www.hrmars.com)

This article is published under the Creative Commons Attribution (CC BY 4.0) license. Anyone may reproduce, distribute, translate and create derivative works of this article (for both commercial and non-commercial purposes), subject to full attribution to the original publication and authors. The full terms of this license may be seen at: http://creativecommons.org/licences/by/4.0/legalcode

Vol. 8(4) 2019, Pg. 824 - 835

http://hrmars.com/index.php/pages/detail/IJARPED JOURNAL HOMEPAGE

Full Terms \& Conditions of access and use can be found at http://hrmars.com/index.php/pages/detail/publication-ethics 


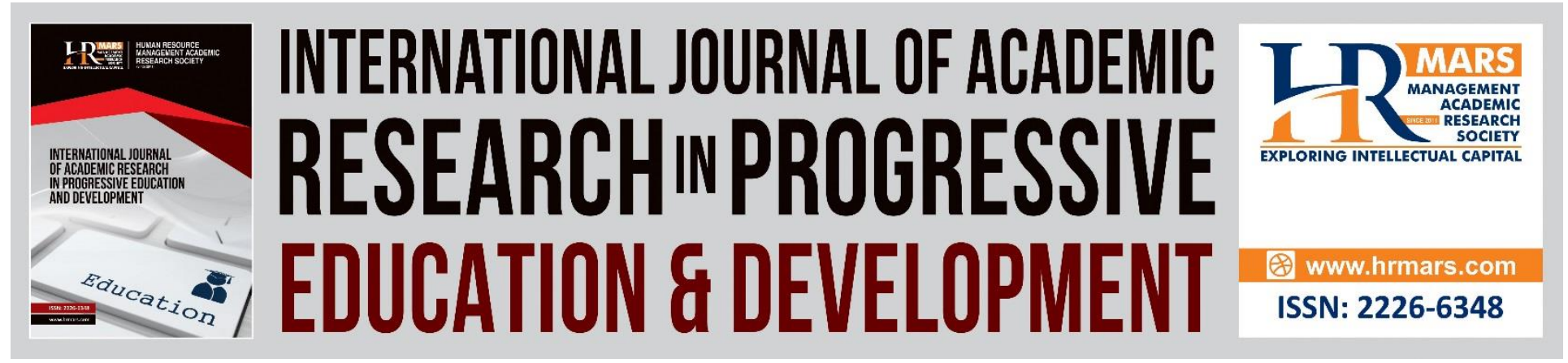

\title{
The Relation of Human Capital and Competitiveness Factor towards Graduate Competencies
}

\author{
${ }^{1}$ Marfunizah Binti Ma'dan, ${ }^{2}$ Muhamad Takiyuddin Bin Ismail, ${ }^{2}$ Sity \\ Daud \\ ${ }^{1}$ Public Management Department, School of Government, College of Law, Government \& \\ International Studies (COLGIS), 06010, Sintok, Universiti Utara Malaysia, Kedah, Malaysia. \\ ${ }^{2}$ Political Science Programme, Faculty of Social Sciences and Humanities (FSSK), Universiti \\ Kebangsaan Malaysia (UKM), 43650 Bangi, Selangor, Malaysia. \\ Email: marfunizah@uum.edu.my
}

\begin{abstract}
Graduate unemployment issues have been related to unused human resources in the country. Mainly, the unemployment of graduates could adversely impact a high-quality and educated workforce. Hence, to answer the unemployment phenomena of our graduates, the research is motivated to investigate the graduates' competency issues in getting jobs. Based on the literature, graduate competency is viewed as the main factor for employment. To grasp the understanding of graduate competency issues in our country, this research has implemented a preliminary study to develop the scale. The competency construct that is specifically used in this study is to identify the influence of human capital and competitiveness factors that may lead to competency among graduates. A total of 30 respondents were randomly selected to represent the actual 384 sample size of the study. The respondents were Higher Education Institutions (HEIs) graduates working in several services organizations in Malaysia. Our findings for the reliability analysis of the survey items showed strong reliability of Cronbach's alpha values within the ranges of $\alpha=.735$ and $\alpha=.926$ for all items. Then, we ran a correlational analysis to understand the relationship between items. The results show that all items were significant at $p$ $<.05$ with Pearson correlation coefficient analysis. To highlight one of the key findings in our research, technical skills relate highly to graduate competency $(r=.564)$. Additionally, the competitiveness factor towards graduates' competency level was highly related to organizational management competitiveness $(r=.665)$, followed by general competitiveness $(r=.556)$, employability competitiveness $(r=.547)$ and dominant competitiveness $(r=.511)$. It is noteworthy to mention that the aggressive competitiveness factor shows the lowest correlation coefficient value $(r=.237)$. Our findings contribute to the understanding of how important it is
\end{abstract}


Vol. 8, No. 4, 2019, E-ISSN: $2226-6348$ @ 2019 HRMARS

to develop human capital with a high level of graduate competency values. Additionally, the research proposes that a competent graduate should be able to compete in a global workforce. Finally, it is also important to note that graduate competency should also be based on positive human values and personalities, and these two should also be augmented.

Keywords: Human Capital, Competitiveness, Competency, Graduate, Higher Education Institutions

\section{Introduction}

Knowledgeable and innovative human capital is an important resource for transforming Malaysia into a service-oriented economy. Thus, Malaysia has a high capacity to produce graduates who are not only knowledgeable in a particular field but can contribute new ideas to their various tasks, and in line with current technological advances. However, there is a need for critical skills, resilience and high innovation value in the ever-changing global economic landscape (Jung \& Lee, 2016; Van der Heijden, 2002). In this regard, many complaints made by current employers from various industries are that most new graduates do not have the required job-specific skills such as weak in English language skills, a reluctance to be self-reliant and not having sufficient readiness for the current job market (Abdullah et al., 2018; Ismail, 2012; Yusof et al., 2013; Wickramasinghe \& Perera, 2010; Mohd Adnan et al., 2012, p. 3). Moreover, some of these young job seekers also expect higher wages and are unrealistic even when they realize that their experience is lacking (Abdullah et al., 2018). As a result, this has raised many issues, including increasing the unemployment rate among graduates. According to statistics from the Department of Statistics Malaysia (2016), the unemployment rate in Malaysia increased to 3.4 percent over 0.3 percent in 2015. Accordingly, the unemployment rate of higher education youth was 15.3 percent compared to the uneducated higher education at 9.8 percent in 2015 (Malaysian National Bank, 2016). The current number of unemployed graduates is expected to increase over time. Moreover, this unemployed graduate scenario not only has a negative economic impact of wasting resources but also has a direct impact on political and social aspects. As a result, the crisis around the demand for talented human capital in Malaysia has also been undertaken to study the entire educational landscape, human capital development, and demand for more competitive talent development particularly to meet global demand. Therefore, this article presents a preliminary analysis based on a pilot study conducted to identify the influence of human capital and competitiveness on graduates' competency level.

\section{Literature Review}

Graduate competence is an understanding of the competencies, skills, and abilities (Velasco, 2014) found in graduates generated from the learning process (Sauber et al., 2008). The principle of a competency model is to refer to individual performance studies that include aspects of personal knowledge, skills, and characteristics that enable an employee to perform certain tasks well and effectively (Nasir et al., 2017). Ali and Marwan (2019) also highlighted that competency could be developed through a career management program to foster one's personal development and help in their proficiency field of work. Therefore, to achieve the goal of creating an educated and competitive graduate, three criteria are considered very important to 
graduates, which in terms of technical ability, self-management with continuous learning, and the ability to socialize while working with others (Yahya et al., 2015).

A study by Pandey and Pandey (2015) found that holistic thinking can develop among students through the encouragement of interpersonal and technical skills. It aims to build holistic thinking by fostering students' attitudes to value, motivate, enhance their learning desires and feelings, and to nurture futuristic thinking in preparation for becoming more globally competitive. Meanwhile, a study by Roulin and Bangerter (2011) found that involvement in additional curriculum activities is one approach that allows graduates to uncover the benefits of unseen skills in their resumes due to limited work experience. Moreover, through this participation, they can improve their personality while developing the necessary work skills such as interpersonal skills, high self-confidence and can show better self-esteem than others when competing for the job they want.

The findings of the study by Abdullah et al. (2018) \& Makki et al. (2015) found that most Malaysian graduates lack self-assurance, pessimistic, and lack of sufficient skills to enter for employment. Besides, graduates are considered less committed to exploring real-world work. Therefore, studies show that job readiness skills include professional skills, technology skills, and social or interpersonal skills; Self-efficacy in employment and job exploration are tools for assessing graduate competence levels closely related to graduate marketability. In addition, these elements enhance the competitiveness of the students towards their capabilities. Besides, to increase the level of competitiveness and addressing skills shortage among current graduates, value-added skills such as interactive personal capability and career-oriented modes like entrepreneurial skills can be cultivated (Dardiri, 2016).

Not only that, but according to Bartos et al. (2015), creativity and innovation skills, as well as aggressive competition, are required to enhance the performance of the company, especially in the field of business. In this regard, the study shows that the elements of aggressive innovation and competitiveness are intertwined in improving firm performance when it comes to organizational goals. In addition, Hatch and Dyer (2004) have found in their study that having employees who have the characteristics of human capital, such as high skill set and ability as well as good manners will improve the performance of an organization while also competing well. Thus, a person with competitiveness can improve their productivity and performance. Therefore, based on the discussion on human capital development and competitiveness above, this study proposes a conceptual framework such as in Figure 1 below: 


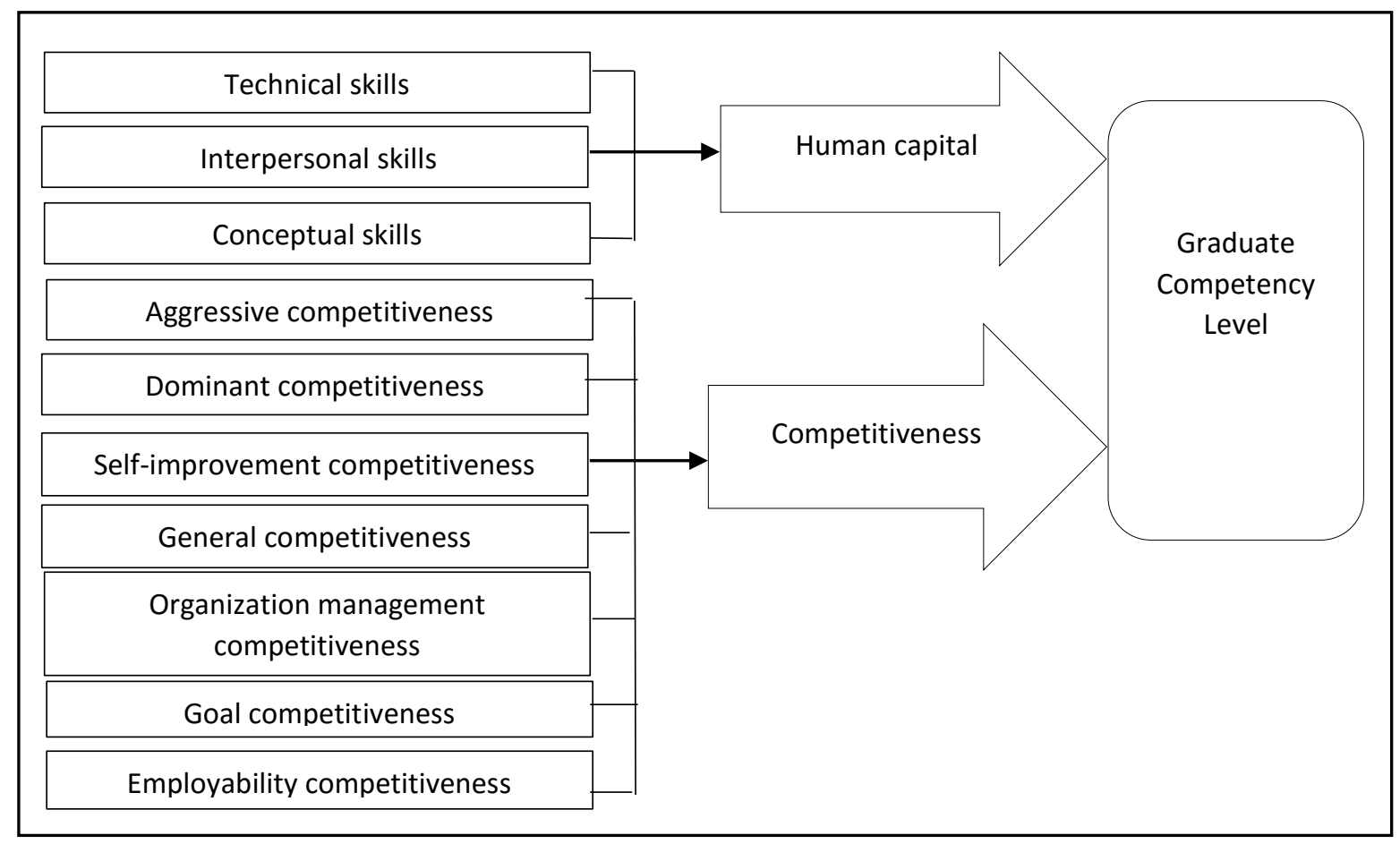

Figure 1: Conceptual Framework towards Enhancing University Graduate Competency Levels

Figure 1 above is a conceptual framework of this study that describes the influence of human capital and competitiveness factors in increasing the competency level of current higher education institutions. Thus, researchers suggest that all of these aspects are taken into account in teaching and learning at institutions of higher learning as factors in human capital development and competitiveness towards increasing levels of competency among HEls while reducing the current unemployment problem. Moreover, the employer nowadays is very selective in the recruitment process, and expect the HEls to produce capable graduates with value-added skills to fill vacant in their organization (Ali \& Marwan 2019). As such, there is an urgent need to be aware of the changes and shifts to enhance graduate's competitiveness with economic and technological change in current.

\section{Methodology}

This preliminary study was conducted to identify the influence of human capital and competitiveness factors on graduates' competency levels. The research unit of this study is a Social Science graduate who is working in the services department in Malaysia. According to the data from the Ministry of Higher Education (2016), this field is found to have the highest number of unemployed graduates, with 28,043 out of a total of 54,103 unemployed graduates. In this regard, the Social Science cluster is also the sphere of services in Malaysia, which is the highest contributing factor to the Malaysian economy, as explained by the Department of Statistics Malaysia (2015). Based on this data, it has been identified that graduates working in the services 
Vol. 8, No. 4, 2019, E-ISSN: 2226-6348 @ 2019 HRMARS

sector are $77.8 \%$ compared to only $22.2 \%$ from other sectors. On the other hand, in 2016 , the number of graduates working in the services sector also accounted for $77.3 \%$ of all other sectors in Malaysia. Therefore, based on the population study by Krejci and Morgan (1970), a total of 384 study samples were needed. However, only 30 respondents were randomly selected for validation of the questionnaire for this study.

\section{Findings and Discussion}

A pilot study was conducted on 30 respondents consisting of graduates that were randomly selected from the services department in Malaysia. In this case, selecting 30 respondents to represent the actual population in the pilot study is sufficient. As Johanson and Brooks (2010, p. 399) have suggested, the 30 respondents selected to conduct the pilot study representing the actual size of the study population are particularly suitable for testing the item scale. Therefore, the Cronbach's alpha values were determined by the researchers so that measurements on the instruments used had a high degree of consistency. According to Bonett and Wright (2014), Cronbach's alpha values of .70 to .95 would indicate that the items constructed were suitable for use. After the analysis, the Cronbach's alpha for all the items constructed was .925. Meanwhile, the Cronbach's alpha values for each variable are as shown in Table 1:

Table 1 Cronbach's Alpha Values by Variables

\begin{tabular}{ccc}
\hline Variable & Total Item & Cronbach's alpha \\
\hline Human Capital & 23 & .735 \\
Competitiveness & 59 & .926 \\
Competency Level & 18 & .702 \\
\hline
\end{tabular}

Table 1 shows the overall Cronbach's alpha values for all three variables of human capital, competitiveness, and competency. Based on the Cronbach's alpha values, all variables had values greater than .70. This indicates that each factor in the item has a high degree of trustworthiness and is highly satisfactory. Therefore, each item is believed to be included in the research questionnaire to analyze human capital and competitive factors in influencing graduates' competency level as the objective of this study.

Next, to analyze the influence of human capital and competitiveness factors on graduate competency, the Pearson correlation analysis was done. According to Kothari $(2004$, p. 141$)$ and Zou et al. (2003), r values close to +1 or -1 have a high or very high correlation between variables. Furthermore, Zou et al. (2003) also stated that $r$ values close to +0.2 or -0.2 are weak, +0.5 or 0.5 are moderate, and +0.8 or -0.8 are very high, but the value of $r=0.0$ has no relation or influence. Whereas Cohen et al. (2007) stated that the correlation values of 0.10 to 0.29 were considered small, the correlation coefficients of 0.30 to 0.49 were considered moderate, and the correlation coefficients between 0.50 and 1.00 were high. Thus, Table 2 presents the overall results of the correlation coefficient analysis showing the influence of human capital and competitiveness factors on the degree of competency of the graduates of this study. 
Table 2 Pearson's Correlation Rating Scale between Human Capital and Competitive Factors on Graduate Competency Levels

\begin{tabular}{lc|c}
\hline & \multicolumn{2}{c}{ Graduate Competency Levels } \\
\cline { 2 - 3 } Variable & \multicolumn{2}{c}{ Correlation coefficient } \\
\cline { 2 - 3 } Human Capital & $r^{2}$ & $P$ \\
i. Technical skills & .564 & 0.01 \\
ii. Interpersonal skills & .406 & 0.05 \\
iii. Conceptual skills & .326 & \\
\hline Competitiveness & & \\
i. Aggressive competitiveness & .237 & \\
ii. Dominance competitiveness & .511 & 0.01 \\
iii. Self-improvement competitiveness & .473 & 0.01 \\
iv. General competitiveness & .556 & 0.01 \\
v. Organization management competitiveness & .665 & 0.01 \\
vi. Goal competitiveness & .492 & 0.01 \\
vii. Employability competitiveness & .547 & 0.01 \\
\hline
\end{tabular}

** Significant at level 0.01

* Significant at level 0.05

Table 2 shows the value of the Pearson correlation coefficient between human capital and competitiveness factors on graduate competency. The results obtained show that all the factors of human capital and competitiveness are significantly related to the degree of competency of graduates at the $p=>0.05$ level (sig-two tailed). Based on the results obtained, the human capital factor that most influences the degree of competency of graduates are from the technical skills aspect with a correlation coefficient of .564. Therefore, the results of this study show that technical skills are the most important skill that an individual must have to perform any field of work. This is because technical skills refer to detailed knowledge of specific fields, following specific procedures and techniques based on various aspects of work such as finance, production, engineering, marketing, and others (Aziz, 2009 \& Md Nasir, 2011). Therefore, every HEls graduate should be provided not only with knowledge of concepts and theories of a particular field of study but also master the technical aspects required in the real workplace. Similar to the results of the study by Yahya et al. (2015), it was found that most of the employers agreed that technical skills are one of the most required skills by many employees in an industry. Besides, these skills are seen to help improve their level of competency in managing their tasks better while improving productivity in the current economy.

The most influential factor affecting graduates' competency is organizational management, with a correlation coefficient of .665. The findings of this study indicate that each graduate must be a leader or a wise manager of strategy and a good decision-maker in the management of their organization. This finding is supported by Colbert et al. (2014), who argue that the effectiveness of organizational management such as strategic decision making, efficient implementation, and networking between employees and other organizations can be influenced 
Vol. 8, No. 4, 2019, E-ISSN: 2226-6348 @ 2019 HRMARS

by good leadership. Therefore, a competent leader is essential to control, shape, and move forward in every activity undertaken in the organization. Moreover, a dedicated and competitive leader can influence the commitment of his employees (Shin et al., 2015), especially in achieving organizational goals.

Furthermore, there are also competitive factors that have correlation values above 0.50 and are considered high, according to Cohen et al. (2007), the general competitiveness of .556, followed by the employability of .547 as well as dominant competitiveness with a correlation value of .511. This indicates that competitiveness of employment, job competitiveness, and dominant competitiveness are also major contributors to graduates' competency levels. This is in line with the findings of Hinsz and Judnt (2005) and Yeoh and Yeoh (2015) that competitive individuals will perform better and harder than others because the higher their competitiveness, the higher their performance will lead to their goal achievement. Moreover, through competition, an individual will be able to demonstrate their ability to others. In this case, a study by Abdullah et al. (2018) also indicated that when student builds up self-knowledge like feel proud of themselves and believe can do things better than others, they can create more confident to compete well in making a career decision. Thus, competitiveness is one of the positive motivational factors that can enhance individual self-esteem towards goal achievement.

Accordingly, employability competitiveness is also an individual's willingness to perform a given task (Othman et al., 2015). Therefore, without the competitiveness of employment, one can find it difficult to show an advantage to others, especially when competing for job opportunities. This is because the characteristics of job competitiveness include general academic skills, rational thinking skills and good personality values categorized as non-technical skills that are also relevant in various occupations and careers (Fatoki, 2014 \& Othman et al., 2015). On the other hand, dominant competitiveness is the need for an individual to appear superior in their reliability than others (Newby \& Klein, 2014). In this regard, a person with dominant competitiveness is more likely to be seen as more powerful and influential than others (Othman et al., 2015; Azman, Shuraimi, \& Yunus, 2018; Hayek, 2018).

Therefore, the results show that dominant competitiveness has a strong influence on one's life when these characteristics will enable one to feel better than others around him, which in turn will increase his motivation to succeed and to pursue his goals.

However, it is seen that aggressive competitive factors have a relatively low impact on graduates' competency level, with only a correlation coefficient of .237 . The results of this study are in line with Othman et al. (2015), who recorded the lowest mean scores on the aggressive competition. However, researchers argue that while students often exhibit low aggressiveness, their quality of life to remain strong in today's more competitive job market will also be affected. Also, the lack of skilled and superior human capital with high competitiveness will adversely affect a country's development and productivity. Therefore, having an aggressive competitive attitude is also important not only for the achievement of individual goals but for organizational success. This is supporting the idea that obtained competent graduates is of paramount crucial for the organization's effectiveness (Pang et al., 2019). Bartos et al. (2015) and Junior (2015) also argued that aggressive competitiveness could enhance an individual's performance and at the same time, increase a company's productivity. Overall, all of these factors of human capital and competitiveness were found to influence the degree of competency of graduates. 
Vol. 8, No. 4, 2019, E-ISSN: 2226-6348 @ 2019 HRMARS

\section{Conclusion and Recommendations}

The implications of globalization and the changes in technology not only impact the political and social world but also pose significant challenges to the economy. In fact, in pursuit of the advanced economic status of the service itself, it also involves social aspects such as job opportunities, educational advances, and high technology that lead to the pursuit of sustainable new talent today. This is in line with the government's goal of strengthening human capital to enhance the country's productivity and economy. As such, the role of various parties, especially the HEls, is required for shaping and producing high-quality graduates as well as adding value such as aspects of their competitiveness, so that they are not only able to market locally but compete nationally.

Overall, this study shows that the element of competitiveness is also important for the country's human development. It means that, to increase our future graduate employability, not only important to supply them with the main aspect of human capital, such as technical abilities, interpersonal skills, and conceptual thinking skills. However, their motivational factor of competitiveness can be cultivated to enhance their level of competencies. Based on this study, the most important competitiveness factors that influence graduate's competency is organizational management competitiveness. These organizational management criteria include the ability to manage the job responsibilities well, such as critical thinking in decision making, good in handling staff, being good as a problem solver, etc. This study indicated that a good leader with a high value of competitiveness is very crucial to handle any problem and changes that come in the organization. More importantly, the dynamic environment nowadays constantly changing and very challenges until the need for huge competition for many organizations. On the other hand, the organization acquires competent people with quality value to increase their competitiveness. Thus, the important evidence of this study is hoped that can be used by those involved in human capital development and the authorities, including policymakers, universities, industry, and graduates, to plan for future career education management prospects carefully and effectively and bring benefits for new talent in the future. As a result, social problems such as unemployment among graduates can be alleviated and resolved over time as well as reduce the waste of energy resources in the country.

The study has some limitations. It is relatively covering a small sample sizes. Therefore, it is desirable to conduct quantitative research with more samples to indicate the influence of human capital and competitiveness factor, specifically to increase the graduate competency level. Apart from that, future research will also be necessary to replicate this study by taking into account the larger context, such doing qualitative research, particularly from the perspective of the employer about the competitiveness level among graduates working in their organization. More importantly, multilevel perspectives on graduate competency level can be guided to improving and structuring a new program in enhancing the performance of new talent in the future. 


\section{References}

Abdullah, N., Hussin, N., Shonubi, O. A., Ghazali, S. R., \& Talib, A. M. (2018). Career Decisionmaking Competence, Self-Knowledge and Occupational Exploration: A Model for University Students. Journal of Technical Education and Training, 10(1), 71-81. DOI: https://10.30880/jtet.2018.10.01.006

Adnan, M. Y., Daud, M. N., Alias, A., \& Razali, M. N. (2012). Importance of Soft Skills in The Real Estates Programmes in Malaysia. Journal of Surveying, Construction \& Property, 3(2), 113.

Ali, A., \& Marwan, A. (2019). Exploring Career Management Competencies in Work-Based Learning (WBL) Implementation. Journal of Technical Educational and Training, 11(1), 159-166.

Aziz, A. (2009). Pembangunan Modal Insan: Asas Pendidikan Negara. Sintok: Penerbit Universiti Utara Malaysia.

Azman, M. N. Bin, Shuraimi, F. binti M., \& Yunus, M. B. M. (2018). Enhancing English Language Learning and Teaching via Qgram (Telegram and Quizlet) Innovation. International Journal of Academic Research in Progressive Education and Development, 7(4), 435-446.

Bartos, P., Kljucnikov, A., Popesko, B., \& Machacek, J. (2015). Are Men More Innovative and Aggressive in Business? Case Study from the Czech Republic. International Journal of Entrepreneurial Knowledge, 2(3), 29-39. DOI: 10.1515/ijek-2015-0014

Bonett, D. G., \& Wright, T. A. (2014). Cronbach's Alpha Reliability: Interval Estimation, Hypothesis Testing, and Sample Size Planning. Journal of Organizational Behavior, 1-13.

Cohen, L., Manion, L., \& Morrisson, K. (2007). Research Method in Education. Sixth Edition. Routledge: New York.

Colbert, A. E., Barrick, M. R., \& Bradley, B. H. (2014). Personality and Leadership Composition in Top Management Teams: Implications for Organizational Effectiveness. Personnel Psychology, 67, 351-387.

Dardiri, A. (2016). Soft Skill and Entrepreneurial Career Guidance Model for Enhancing Technical Vocational Education and Training's Graduates Competitiveness. Innovation of Vocational Technology Education, 12(1), 1-7.

Department of Statistics Malaysia. (2016). Labor Demand and Supply: DOSM Perspectives. Retrieved from https://www.dosm.gov.my.

Fatoki, O. (2014). Final Year Undergraduate Students' Perception of their Non-Technical Skills. Mediterranean Journal of Social Sciences, 5(7), 43-47. Doi:10.5901/mjss. 2014.v5n7p43

Harian, B. (2018). Teks Ucapan Penuh Kajian Separuh Penggal RMK-11 2016-2020. Retrieved from

https://www.bharian.com.my/berita/nasional/2018/10/487719/teks-ucapan-penuhkajian-separuh-penggal-rmk-11-2016-2020.

Hatch, N. W., \& Dyer, J. H. (2004). Human Capital and Learning as a Source of Sustainable Competitive Advantage. Strategic Management Journal, 25, 1155-1178.

Hayek, A. M. A. (2018). The Relationship Between Sales Revenue and Net Profit with Net Cash Flows from Operating Activities in Jordanian Industrial Joint Stock Companies, International Journal of Academic Research in Accounting, Finance and Management Sciences 8 (3): 149-162. 
Heijden, V. D. B. I. J. M. (2002). Organizational influences upon the development of professional expertise in SME's. Journal of Enterprising Culture, 9 (4), 367-406.

Hinsz, V. B., \& Jundt, D. K. (2005). Exploring Individual Differences in a Goal-Setting Situation Using the Motivational Trait Questionnaire. Journal of Applied Social Psychology, 35(3), 551-571.

Ismail, M. H. (2012). Kajian Mengenai Kebolehpasaran Siswazah di Malaysia: Tinjauan dari Perspektif Majikan. Prosiding Perkem VII 2, 906-913.

Johanson, G. A., \& Brooks, G. P. (2010). Initial Scale Development: Sample Size for Pilot Studies. Educational and Psychological Measurement, 70(3), 394-400.

Junior, A. B. O. (2015). The Aggressive Competitiveness Influence on the Retailer Company Performance. Future Studies Research Journal: Trends and Strategies, 7(1), 156-183.

Jung, J., \& Lee, S. J. (2016). Influence of university prestige on graduate wage and job satisfaction: the case of South Korea. Journal of Higher Education Policy and Management, 38(3), 297315. http://dx.doi.org/10.1080/1360080X.2016.1174408

Kementerian Pendidikan Tinggi Malaysia. (2016). Peratusan Status Graduan Universiti Awam 2015. Retrieved http://www.data.gov.my

Kothari, C. R. (2012). Research Methodology: Methods and Techniques. Second Revised Edition. New Age International Publishers: India.

Krejcie, R. V., \& Morgan, D. W. (1970). Determining sample size for research activities. Educational and psychological measurement, 30(3), 607-610.

Makki, B. I., Salleh, R., Memon, M. A., \& Harun, H. (2016). The Relationship between Work Readiness Skills, Career Self-efficacy and Career Exploration among Engineering Graduates: A Proposed Framework. Research Journal of Applied Sciences, Engineering and Technology, 10(9), 1007-1011.

Malaysian National Bank. (2016). Laporan Tahunan 2016. Pengangguran Belia di Malaysia: Perkembangan dan Pertimbangan Dasar. 109-117. Retrieved from https://www.bnm.gov.my/files/publication/ar/bm/2016/cp04_003_rencana.pdf

Nasir, M. A. N., Ali, D. F., Noordin, M. K., \& Nordin, M. S. (2011). Technical skills and non-technical skills: predefinition concept. In Proceedings of the IETEC'11 Conference, Kuala Lumpur, Malaysia.

Nasir, N., Adam, S. B., Rosli, N. N., Abdullah, M. S., \& Azman, M. N. A. (2017). Kompetensi Pembimbing dalam Sistem Latihan Kemahiran Dua Hala: Satu Sorotan Literatur. Sains Humanika, 9, 1-5.

Newby, J. L., \& Klein, R. G. (2014). Competitiveness Reconceptualized: Psychometric Development of the Competitiveness Orientation Measure as a Unified Measure of Trait Competitiveness. The Psychological Record, 64, 879-895.

Othman, N., Khasbullah, K. K., \& Wahid, A. H. (2015). Tahap Daya Saing Pelajar Institusi Pengajian Tinggi di Semenanjung Malaysia. Jurnal Pendidikan Malaysia, 40(2), 139-149.

Pandey, M., \& Pandey, P. (2015). Global Employability of Unemployment Trough Soft Skills. International Journal of Multidisciplinary Approach of Studies, 2(2), 73-77.

Pang, E., Wong, M., Leung, C. H., Coombes, J. (2019). Competencies for Fresh Graduates' Success at Work: Perspectives of Employers. Industry and Higher Education, 33(1), 55-65. https://doi.org/10.1177/0950422218792333 
Roulin, N., \& Bangerter, A. (2011). Students' Use of Extra-Curricular Activities for Positional Advantage in Competitive Job Markets. Journal of Education and Work, 26(1), 21-47.

Sauber, M. H., McSurely, H. B., \& Rao Tummala, V. M. (2008). Developing Supply Chain Management Program: A Competency Model. Quality Assurance in Education, 16(4), 375391. doi:10.1108/09684880810906517/full/html

Shin, Y., Sung, S. Y., Choi, J. N., \& Kim, M. S. (2015). Top Management Ethical Leadership and Firm Performance: Mediating Role of Ethical and Procedural Justice Climate. Journal of Business Ethics, 129, 43-57. doi: 10.1007/s10551-014-2144-5

Venhorst, V., Dijk, J. V., \& Wissen, L. V. (2010). Do the Best Graduates Leave the Peripheral Areas of The Netherlands? Journal of Economic and Social Geography. 101(5), 521-537.

Velasco, M. S. (2014). Do Higher Education Institutions Make a Difference in Competence Development? A Model of Competence Production at University. Higher Education, 1-21. doi: 10.1007/s10734-014-9725-1

Wickramasinghe, V., \& Perera, L. (2010). Graduates', University Lecturers' and Employers' Perceptions towards Employability Skills. Education \& Training, 52(3), $226-244$.

Yahya, N., Rasul, M. S., \& Yasin, R. M. (2015). Social Skills and Social Values in Malaysian Dual Training System Apprenticeship. In International Conference on Innovation in Engineering and Vocational Education, 170-175.

Yeoh, J. P. S., \& Yeoh, P. A. (2015). Competitiveness between Ethnic Malays and Ethnic Chinese in Malaysia. Journal of Psychology, 2(1), 16-21.

Yusof, N., Jamaluddin, Z., \& Lazim, M. N. (2013). Persepsi Pelajar Prasiswazah Terhadap Kebolehpasaran Graduan dan Persaingan dalam Pasaran Pekerjaan. Journal Personalia Pelajar, 16, 77-92.

Zou, K. H., Tuncali, K., \& Silverman, S. G. (2003). Correlation and Simple Linear Regression. Radiology, 617-622. 